\title{
Effects of hormones, cyclic AMP analogues and growth factors on steel factor (SF) production in mouse Sertoli cell cultures
}

\author{
Y. Tajima ${ }^{1}$, Y. Nishina ${ }^{1}$, U. Koshimizu ${ }^{1}$, T. Jippo ${ }^{2}$, Y. Kitamura ${ }^{2}$ and \\ Y. Nishimune ${ }^{1 *}$ \\ ${ }^{1}$ Research Institute for Microbial Diseases, Osaka University, Yamada-oka, Suita, Osaka 565, Japan; \\ and ${ }^{2}$ Department of Pathology, Osaka University Medical School, Suita, Osaka 565, Japan
}

\begin{abstract}
Regulation of steel factor (SF) production in Sertoli cells from postnatal mouse testes was studied in a mast cell-Sertoli cell coculture system. Treatment of Sertoli cells with dibutyryl cAMP $\left(50-1000 \mu \mathrm{mol} \mathrm{l}^{-1}\right)$, forskolin (1-25 mmol l-1), and cholera toxin $\left(10 \mu \mathrm{g} \mathrm{ml}^{-1}\right)$ increased SF production, whereas FSH and theophylline had no significant effect. Furthermore, growth factors and testosterone, which would play some roles in spermatogenesis, were also tested, but none of these stimulated SF production. The constitutive production of SF may, rather, reflect the physiological condition of Sertoli cells in vivo.
\end{abstract}

\section{Introduction}

Spermatogenesis is a temporally regulated developmental process by which gonadotrophin-responsive somatic Sertoli cells and Leydig cells act interdependently to direct the maturation of germ cells (Bellve, 1979). In addition to the hormonal regulation of these cells, paracrine effects of supporting cells on spermatogenesis and cell-to-cell interactions among germ cells, Sertoli cells, peritubular myoid cells and Leydig cells are also considered to regulate spermatogenesis (Skinner, 1991). Although many lines of evidence show that these supporting cells produce many growth factors (Bellve and Zheng, 1989), little information on the mechanism of growth-factor-mediated germ cell differentiation is available.

Mutation at the murine dominant white-spotting $(W)$ and the steel $(S i)$ loci leads to defects in haematopoiesis, melanogenesis and gametogenesis (Russell, 1979). Recent progress in the studies of these loci has demonstrated that the $W$ gene encodes a cell surface tyrosine kinase receptor, called c-kit (Chabot $e t$ al., 1988), and that the Sl gene encodes the ligand of c-kit (Witte, 1990), a polypeptide called here steel factor (SF). In the testes, we have reported that the $W$ and $S l$ genes play important roles in spermatogenesis (Koshimizu et al., 1991; Sawada et al., 1991; Tajima et al., 1991a, b). Thus, the signal transduction system of the c-kit receptor and its ligand is an interesting candidate for paracrine stimulation of germ cell proliferation and differentiation (Yoshinaga et al., 1991). Like macrophage colonystimulating factor (M-CSF) (Stein et al., 1990), SF can be expressed in both membrane-bound and soluble forms (Anderson et al., 1990). In vivo, the membrane-bound form is probably the physiologically relevant ligand for c-kit. Recently, in situ hybridization studies showed that SF mRNA is expressed in haematopoietic tissues, mesenchymal cells and gonads along the migratory pathways of melanoblasts and primordial germ

*Correspondence.

Received 18 January 1993. cells and in their destination site during embryogenesis (Matsui et al., 1990). In spermatogenesis, we demonstrated that Sertoli cells are a main producer of the ligand, i.e. Sertoli cells derived from $+1+$ and $W^{v} / W^{v}$, but not $S l^{d} / S l^{d}$ mutant mice produced biologically active SF in a membrane-bound form (Tajima et al., 1991a). The SF produced by Sertoli cells acts on germ cells that have the c-kit receptor on their cell surface and would stimulate their growth and differentiation. In connection with the regulation of SF expression, no evidence for any inducer is available at present, except for dibutyryl cAMP (Rossi et al., 1991).

Among the agents that affect the functions of spermatogenesis, we are interested in the effects of hormones and growth factors that potentially have a local stimulatory action in the testes on the production of biologically active SF, as it has been shown that some growth factors influence Sertoli cells (Boockfor and Schwarz, 1990) and that others are present within the testis (Mayerhofer et al., 1991) and may modulate cell proliferation and differentiation by an autocrine and/or paracrine regulatory mechanism.

\section{Materials and Methods}

Mice

C57BL/ 6 mice were raised in our animal facilities. Mast-celldeficient-adult (WB-W $/+\times \mathrm{C} 57 \mathrm{BL} / 6-\mathrm{W}^{v} /+$ ) F $1-W / W^{v}$ mice $\left(W / W^{v}\right)$ were purchased from SLC (Hamamatsu).

\section{Materials}

Bovine serum albumin (BSA), transferrin, insulin, collagenase (Type 1-A), hyaluronidase (Type 1-S), deoxyribonuclease 1, dibutyryl cyclic AMP (dbcAMP), forskolin, theophylline and 5-bromodeoxyuridine (BrdU) were purchased from Sigma Chemical Co. (St Louis, MO). Human recombinant basic fibroblast growth factor (bFGF) and transforming growth factor $\alpha$ 
(TGF- $\alpha$ ) were purchased from Gibco BRL (Gaithersburg, MD). Human recombinant insulin-like growth factor I (IGF-I: Amersham, UK), human recombinant transforming growth factor- $\beta 1$ (TGF- $\beta 1$ : Nacalai tesque. Inc., Kyoto), mouse nerve growth factor (NGF: Wako Chemical, Osaka), human interleukin $1 \alpha$ (IL-1 $\alpha$ : Boehringer Mannheim, Mannheim), cholera toxin (List Biological Laboratories, Campbell, CA), and $\boldsymbol{\alpha}$ modified Eagle's medium ( $\alpha$ MEM) (Flow Laboratories, Irvine) were purchased. Ovine follicle-stimulating hormone (NIADDKoFSH-16) was supplied by NIADDK-NIH (Bethesda, MA). Each of the agents was dissolved in PBS or ethanol, sterilized, and diluted to the appropriate concentration with basal medium. Mouse anti-BrdU monoclonal antibody (Becton-Dickinson, Mountain View, CA), Vectastain Elite ABC anti-mouse IgG, and biotin-avidin-peroxidase kit (Vector Laboratories, Burlingame, CA) were used for the detection of mast cells in S-phase.

\section{Mast cell cultures}

Homogeneous populations of cultured mast cells were obtained by culturing bone marrow cells of $+/+$ or $W / W^{v}$ mice at $10^{6}$ cells ml ${ }^{-1}$ in $\alpha$-MEM supplemented with $10^{-4} \mathrm{~mol}$ $\beta$-mercaptoethanol $\mathrm{I}^{-1}, 10 \%$ fetal calf serum (Hazleton Biologics Inc., Lenexa, KS), 100 iu penicillin $\mathrm{ml}^{-1}, 100 \mu \mathrm{g}$ streptomycin $\mathrm{ml}^{-1}$, and $10 \%$ pokeweed mitogen-stimulated spleen cell conditioned medium (Nakahata et al., 1982). Half the medium was replaced every 7 days, and cells cultured for more than four weeks were used in the experiments, as described by Nakano et al. (1985).

\section{Preparation of Sertoli cell cultures}

Primary Sertoli cell-enriched cultures from 13- or 16- to 20day-old mice were prepared as described by Dorrington $e t$ al. (1975) with some modifications (Tung et al., 1984; Tajima et al., 1991a). This culture is reported to have more than $95 \%$ purity of Sertoli cells. Briefly, seminiferous tubules were prepared by sequential collagenase and hyaluronidase digestion. Tissue explants were allowed to adhere and to form confluent monolayers on 24-well culture plates for 4 days in serum-free defined medium (SFDM) of $\alpha$-MEM, containing $2 \mathrm{mg} \mathrm{BSA} \mathrm{ml}^{-1}, 5 \mu \mathrm{g}$ insulin $\mathrm{ml}^{-1}$, and $5 \mu \mathrm{g}$ transferrin $\mathrm{ml}^{-1}$, at $37^{\circ} \mathrm{C}$ in a humidified atmosphere containing $5 \% \mathrm{CO}_{2}$ and $95 \%$ air. Some germ cells were trapped in the aggregates but they tended to degenerate during culture.

\section{Coculture of mast cells with Sertoli cells}

For coculture with Sertoli cells, $5 \times 10^{4}$ mast cells suspended in $1 \mathrm{ml}$ of SFDM containing the above reagents were added to cultures of Sertoli cells on day 4 in 24-well plates and incubated at $37^{\circ} \mathrm{C}$ for $24 \mathrm{~h}$ in a humidified atmosphere containing $5 \% \mathrm{CO}_{2}$ and $95 \%$ air. The medium was then removed and the cells were cultured in fresh SFDM for $24 \mathrm{~h}$ at $37^{\circ} \mathrm{C}$ under the same conditions.

\section{Assay of biologically active SF}

Mast cells can proliferate in the presence of SF. The mast cell culture was used to assess biologically active SF. BrdU
Table 1. Effect of various substances on the production of steel factor in Sertoli cell cultures

\begin{tabular}{llc}
\hline Addition & Concentration & $\begin{array}{c}\text { Increase of } \\
\text { labelled mast cells } \\
\text { to control (\%) }\end{array}$ \\
\hline FSH & $0.01-1 \mu \mathrm{g} \mathrm{ml}^{-1}$ & $\mathrm{~N}$ \\
dbcAMP & $0.05-1 \mathrm{mmol} \mathrm{l}^{-1}$ & 62 \\
Forskolin & $1-100 \mu \mathrm{mol} \mathrm{l}^{-1}$ & 55 \\
Cholera toxin & $0.1-10 \mu \mathrm{g} \mathrm{ml}^{-1}$ & 30 \\
Theophylline & $1-100 \mu \mathrm{mol} \mathrm{l}^{-1}$ & $\mathrm{~N}$ \\
Testosterone & $0.01-10 \mu \mathrm{mol} \mathrm{l}^{-1}$ & $\mathrm{~N}$ \\
bFGF & $1-300 \mathrm{ng} \mathrm{ml}^{-1}$ & $\mathrm{~N}$ \\
IGF-I & $1-300 \mathrm{ng} \mathrm{ml}^{-1}$ & $\mathrm{~N}$ \\
TGF- $\alpha$ & $1-100 \mathrm{ng} \mathrm{ml}^{-1}$ & $\mathrm{~N}$ \\
TGF- $\beta 1$ & $0.1-60 \mathrm{ng} \mathrm{ml}^{-1}$ & $\mathrm{~N}$ \\
NGF & $1-100 \mathrm{ng} \mathrm{ml}^{-1}$ & $\mathrm{~N}$ \\
IL-1 $\alpha$ & $0.1-30 \mathrm{U} \mathrm{ml}^{-1}$ & $\mathrm{~N}$ \\
& &
\end{tabular}

Sertoli cell cultures from 16-20-day-old mice were cocultured with mast cells in serum free defined medium (SFDM) supplemented with various concentrations of hormones, growth factors and other agents for $24 \mathrm{~h}$. The effect of various substances on the number of labelled mast cells were studied at different concentrations within the range shown and the data were taken at concentrations giving the maximum response, and demonstrated as the relative change to the control with no additions. Values were obtained from four independent cultures. The number of labelled and non-labelled mast cells (600-700) was counted. The percentage of mast cells that incorporated bromodeoxy-uridine (BrdU) after $48 \mathrm{~h}$ of co-culture was studied and control medium with no addition gave $3-4 \%$. N: no increase in labelled mast cells by the addition of the substance at any concentration, dbcAMP: dibutyryl cAMP; bFGF: basic fibroblast growth factor; IGF-I: insulin-like growth factor-I; TGF- $\alpha$ : transforming growth factor- $\alpha$; TGF- $\beta 1$ : transforming growth factor- $\beta 1$; NGF; nerve growth factor; IL-1 $\alpha$ : interleukin $1 \alpha$.

$\left(3 \mu \mathrm{g} \mathrm{ml}^{-1}\right)$ was added to the culture dishes $48 \mathrm{~h}$ after the initiation of coculture and cells were incubated at $37^{\circ} \mathrm{C}$ for $30 \mathrm{~min}$. The proportion of mast cells in S-phase that incorporated BrdU was measured as described by Tajima et al. (1991a).

\section{Results}

Effects of FSH and various agents on the production of SF in Sertoli cell cultures

Biologically active SF production can be assessed by mast cells cocultured with Sertoli cells as the increase in the number of mast cells in S-phase mediated by the c-kit receptor (Tajima et al., 1991a). Sertoli cells have FSH receptors, and receptor activation by FSH induces many specific Sertoli cell functions through cAMP-dependent pathways (Means et al., 1980). The effect of FSH on the production of SF in Sertoli cell cultures was first studied on 16-20-day-old animals. Although FSH, at concentrations of $0.1-1 \mu \mathrm{g} \mathrm{ml}^{-1}$, can induce the production of plasminogen activator in this type of Sertoli cell culture (Maekawa et al., 1988), no stimulation of SF production was observed in Sertoli cell cultures from 16-20-day-old animals. In contrast, the agents causing intracellular high cAMP concentrations induced SF production in Sertoli cell cultures from 1620-day-old animals (Table 1). Many growth factors, hormones Downloaded from Bioscientifica.com at 04/26/2023 11:29:29AM 

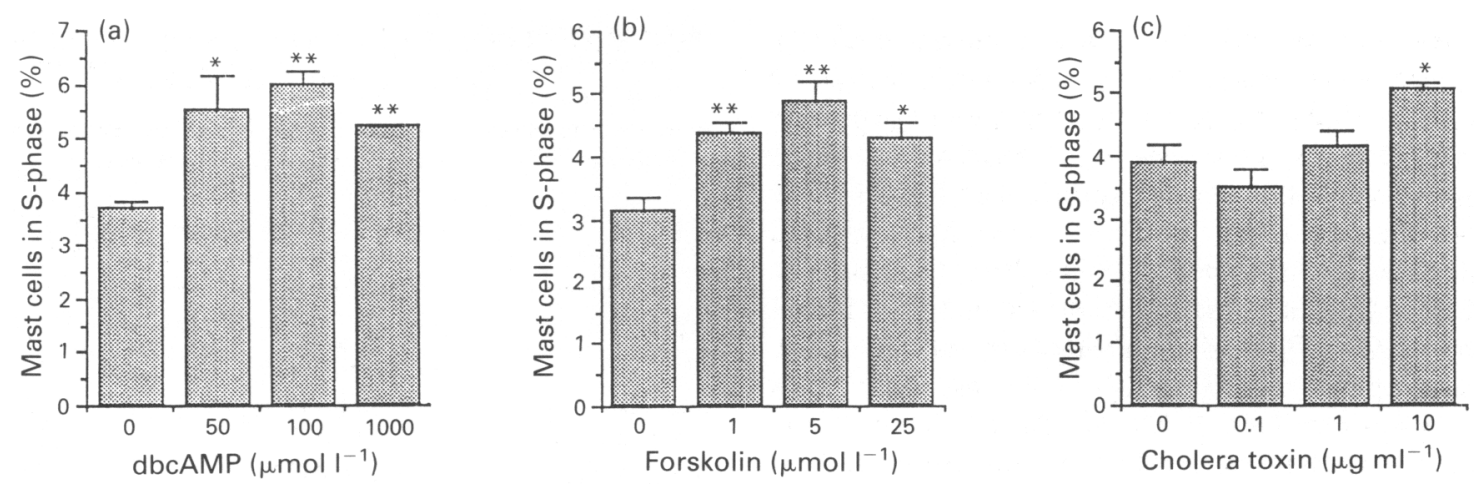

Fig. 1. Effects of (a) dibutyryl cAMP (dbcAMP), (b) forskolin and (c) cholera toxin on the producton of biologically active steel factor (SF) in Sertoli cell cultures. Sertoli cells were cocultured with mast cells in serum-free defined medium (SFDM) supplemented with reagents for $24 \mathrm{~h}$. Percentages of mast cells incorporating 5-bromodeoxyuridine (BrdU) were determined after $48 \mathrm{~h}$ of coculture. Each column represents the mean of four cultures: bars are SEM. ${ }^{* *}, P<0.01 ;{ }^{*}, P<0.05$ compared with control $(0)$ by Student's $t$ test.

and some other agents are produced in the gonads or have some effect on gonadal cells (Bellve and Zheng, 1989). The effect of these factors and agents on the production of $\mathrm{SF}$ in Sertoli cells was determined by adding the following substances to the SFDM:bFGF, IGF-I, TGF- $\alpha$, TGF- $\beta$ I, nerve growth factor (NGF), IL-I $\alpha$, and testosterone. There was no increase in the number of mast cells in S-phase by the additions of these agents (Table I). Thus, these substances did not stimulate the production of SF in Sertoli cell cultures from 16-20-day-old animals in vitro.

Effects of $d b c A M P$, forskolin and cholera toxin on the production of SF in Sertoli cell cultures

A relationship between the dose of $\mathrm{dbcAMP}$ and the number of mast cells in S-phase was demonstrated (Fig. 1a). Increasing the dose of dbcAMP (50 to $1000 \mu \mathrm{mol} \mathrm{l}^{-1}$ ) stimulated biologically active SF production by Sertoli cell cultures from 16-20day-old animals. To determine whether the stimulation of production with $\mathrm{dbcAMP}$ was a physiological response to intracellular CAMP, we used two agents, forskolin and cholera toxin, which activate adenylyl cyclase, with resultant high intracellular CAMP concentrations. Forskolin, a direct activator of the catalytic subunit of adenylyl cyclase (Seamon et al., 1981), increased Sertoli cell SF production at $1-25 \mu \mathrm{mol} \mathrm{l}^{-1}$ (Fig. 1b). Cholera toxin, a Gs protein activator (Moss and Vaughan, 1979), also induced a significant increase in SF production, at $10 \mu \mathrm{g} \mathrm{ml}^{-1}$, in the culture (Fig. Ic). However, theophylline, an inhibitor of cAMP phosphodiesterase, thought to increase intrinsic cAMP, had no significant effects (Table 1). These drugs did not stimulate indicator mast cells when used without Sertoli cells or on indicator $W / W^{v}$ mutant mast cells with a defective c-kit receptor (data not shown). These results indicate that the observed effect of the drugs generating cAMP is mediated by the c-kit receptor and also by Sertoli cell stimulation of mast cells.

\section{Effects of FSH on SF production in Sertoli cell cultures from younger mice}

As the Sertoli cells of younger mice were stimulated to transcribe SF mRNA by FSH (Rossi et al., 1993), we checked
Table 2. Effect of FSH on the production of steel factor in Sertoli cell cultures of 13-day-old mice

\begin{tabular}{lcc}
\hline & \multicolumn{2}{c}{ Rate of mast cells in S-phase (\%) } \\
\cline { 2 - 3 } Treatment & $+1+$ & W/W \\
\hline Control & $2.2 \pm 0.2$ & 0 \\
FSH $\left(0.1 \mu \mathrm{g} \mathrm{ml}^{-1}\right)$ & $2.3 \pm 0.3$ & 0 \\
FSH $\left(1 \mu \mathrm{g} \mathrm{m}^{-1}\right)$ & $1.8 \pm 0.2$ & 0 \\
\hline
\end{tabular}

Sertoli cells of 13-day-old mice were cocultured with mast cells from $+1+$ or $W / W^{v}$ mice in serum-free defined medium (SFDM) supplemented with FSH for $24 \mathrm{~h}$. Values are means \pm SEM of four samples. The percentage of mast cells that incorporated 5-bromodeoxyuridine ( $\mathrm{BrdU})$ after $48 \mathrm{~h}$ of coculture was demonstrated.

whether biologically active SF production is stimulated by FSH in Sertoli cell cultures from 13-day-old mice. These Sertoli cell cultures could support the entry of $+/+$ mast cells but not $W /$ $W^{v}$ mast cells into S-phase, indicating that Sertoli cell cultures from 13-day-old mice produced a biologically active SF (Table 2). However, no stimulation of FSH $\left(0.1\right.$ and $\left.1 \mu \mathrm{g} \mathrm{ml}^{-1}\right)$ was observed.

\section{Discussion}

Several lines of evidence have indicated that c-kit and SF are expressed during spermatogenesis (Motro et al, 1991). Defects in $W$ mutants appear to be intrinsic to stem cells, and the c-kit gene is expressed in male germ cells, particularly in type A spermatogonia (Manova et al., 1990), whereas defects in $\mathrm{Sl}$ mutants appear to lie in the microenvironment in which the stem cells grow, migrate and differentiate. The microenvironment was shown to contain SF produced by Sertoli cells (Tajima et al., 1991a). Thus, one of the mechanisms of the predicted interaction between germ cells and Sertoli cells was identified as signal transduction via c-kit and SF (Yoshinaga et al., 1991). These results promoted our specific interest in the regulation of SF production by Sertoli cells, especially regarding the role of hormones and locally produced growth factors, including TGF- $\alpha$, TGF- $\beta 1$, IGF-I, NGF, bFGF, and IL-1 $\alpha$ (Skinner, 1991). 
Although testosterone and these growth factors could be related to germ cell development or function, or to Sertoli cell functions, in the study reported here they did not have any effect on SF production by Sertoli cells, indicating that these reagents would not affect spermatogenesis via interaction of c-kit and SF.

The binding of FSH to specific cell surface receptors activates adenylyl cyclase, which leads to intracellular cAMP accumulation (Means et al., 1976), and cAMP-dependent protein kinase (Fakunding and Means, 1977) is known to cause specific gene activation. Thus, stimulation of Sertoli cells by FSH results in increased synthesis of androgen-binding protein (Dorrington $e t$ al., 1975), inhibin (Bicsak et al., 1987), plasminogen activator (Lacroix et al., 1981) and transferrin (Skinner and Griswold, 1982). A delay in the treatment of cultured Sertoli cells by FSH results in a loss of FSH dependency in some genes, but not in others. A possible explanation of this result is that there is a difference in the threshold concentration of intracellular cAMP required for the induction of specific genes if FSH treatment is delayed (Hall et al., 1990). In our experiments, Sertoli cells were allowed to become attached for 4 days before FSH treatment. This might explain the lack of FSH effect on SF activity, although, in another study, it was found that the response of Sertoli cell cultures still remained with regard to plasminogen activator production (Maekawa et al., 1988).

Sertoli cells develop refractoriness to FSH stimulation with the age of the sexually immature animals (Means et al., 1980). FSH stimulation of transcriptional activity could be demonstrated in Sertoli cell cultures from 13-day-old mice but not from 18-day-old mice (Rossi et al., 1990). Rossi et al. (1993) reported that SF mRNA expression is stimulated by FSH in Sertoli cell cultures from 13-day-old mice. However, we did not observe stimulation by FSH $\left(0.1\right.$ and $\left.1 \mu \mathrm{g} \mathrm{ml}^{-1}\right)$ of SF production in both Sertoli cell cultures from 13-day-old and from 16-20-day-old mice.

The difference between the effect of dbcAMP and FSH treatment on SF production may result from differences in the access rate to subcellular compartments for exogenous dbcAMP versus endogenous cAMP induced in response to $\mathrm{FSH}$ or produced by cAMP phosphodiesterase inhibition by theophylline. Although the stimulatory effect of dbcAMP on both biologically active SF production and its mRNA expression (Rossi et al., 1991) has been demonstrated, this might not necessarily reflect the physiological conditions, but may reflect some pharmacological effect of cAMP on Sertoli cells. The constitutive production of SF may, rather, reflect the physiological condition of Sertoli cells in vivo.

The authors wish to thank the Pituitary Hormone Distribution Program, NIADDK, USA for the gift of FSH. This work was supported in part by a Grant-in-Aid for Scientific Research from the Ministry of Education, Science, and Culture of Japan and a grant from fellowships of the Japan Society for the Promotion of Science for Japanese Junior Scientists (UK).

\section{References}

Anderson DM, Lyman SD, Baird A, Wignall JM, Eisenman J, Rauch C, March CJ, Boswell HS, Gimpel SD, Cosman D and Williams DE (1990) Molecular cloning of mast cell growth factor, a hematopoietin that is active in both membrane bound and soluble forms Cell 63 235-243
Bellve AR (1979) The molecular biology of mammalian spermatogenesis Oxford Reviews of Reproductive Biology pp 159-261 Ed. CA Finn. Oxford University Press, London and New York

Bellve AR and Zheng W (1989) Growth factors as autocrine and paracrine modulators of male gonadal functions Journal of Reproduction and Fertility 85 $771-793$

Bicsak TA, Vale W, Tucker EM, Cappel S and Hseuh AJW (1987) Hormonal regulation of inhibin production by cultured Sertoli cells Molecular and Cellular Endocrinology $49211-217$

Boockfor FR and Schwarz LK (1990) Fibroblast growth factor modulates the release of transferrin from cultured Sertoli cells Molecular and Cellular Endocrinology 73 187-194

Chabot B, Stephenson DA, Chapman VM, Besmer P and Bernstein A (1988) The proto-oncogene c-kit encoding a transmembrane tyrosine kinase receptor maps to the mouse $W$ locus Nature 335 88-89

Dorrington H, Roller NF and Fritz IB (1975) Effects of follicle-stimulating hormone on cultures of Sertoli cell preparation Molecular and Cellular Endocrinology 3 57-70

Fakunding JL and Means AR (1977) Characterization and follicle-stimulating hormone action of Sertoli cell cyclic AMP-dependent protein kinases Endocrinology 101 1358-1368

Hall SH, Conti M, French FS and Joseph DR (1990) Follicle-stimulating hormone regulation of androgen-binding protein messenger RNA in Sertoli cell cultures Molecular Endocrinology 4 349-355

Koshimizu U, Sawada K, Tajima Y, Watanabe D and Nishimune Y (1991) Whitespotting mutations affect the regenerative differentiation of testicular germ cells: demonstration by experimental cryptorchidism and its surgical reversal Biology of Reproduction 45 642-648

Lacroix M, Parvinen M and Fritz IB (1981) Localization of testicular plasminogen activator in discrete portions (stage VII and VIII) of the seminiferous tubule Biology of Reproduction 25 143-146

Maekawa M, Sakamaki K, Sawada K and Nishimune Y (1988) Plasminogen activator secreted by Sertoli cells in response to retinoids Molecular Andrology $1331-336$

Manova K, Nocka K, Besmer P and Bachvarova RF (1990) Gonadal expression of c-kit encoded at the $W$ locus of the mouse Development $\mathbf{1 1 0}$ 1057-1069

Matsui Y, Zsebo KM and Hogan BL (1990) Embryonic expression of a haematopoietic growth factor encoded by the $S l$ locus and the ligand for c-kit Nature $347667-669$

Mayerhofer A, Russell LD, Grothe C, Rudolf M and Gratzl M (1991) Presence and localization of a $30-\mathrm{kDa}$ basic fibroblast growth factor-like protein in rodent testes Endocrinology 129 921-924

Means AR, Fakunding JL, Huckins C, Tindall DJ and Vitale R (1976) Folliclestimulating hormone, the Sertoli cell and spermatogenesis Recent Progress In Hormone Research 32 477-527.

Means AR, Dedman JR, Tash JS, Tindall DJ, Van SM and Welsh MJ (1980) Regulation of the testis Sertoli cell by follicle stimulating hormone Annual Review of Physiology 42 59-70

Moss J and Vaughan M (1979) Activation of adenylate cyclase by choleragen Annual Review of Biochemistry 48 581-600

Motro B, Der Kooy DV, Rossant J, Reith A and Bernstein A (1991) Contiguous patterns of c-kit and steel expression: analysis of mutations at the $W$ and $S l$ loci Development 113 1207-1221

Nakahata T, Spicer SS, Cantey JR and Ogawa M (1982) Clonal assay of mouse mast cell colonies in methylcellulose culture Blood $60352-361$

Nakano T, Sonoda T, Hayashi C, Yamatodani A, Kanayama Y, Yamamura T, Asai H, Yonezawa T, Kitamura Y and Galli SG (1985) Fate of bone marrow-derived cultured mast cells after intracutaneous, intraperitoneal and intravenous transfer into genetically mast cell deficient $W / W^{\prime}$ mice Joumal of Experimental Medicine 162 1025-1043

Rossi P, Grimaldi P, Blasi F, Geremia R and Verde P (1990) Follicle-stimulating hormone and cyclic AMP induce transcription from the human urokinase promotor in primary cultures of mouse Sertoli cells Molecular Endocrinology 4 940-946

Rossi P, Albanesi C, Grimaldi P and Geremia R (1991) Expression of the mRNA for the ligand of c-kit in mouse Sertoli cells Biochemical and Biophysical Research Communications $176910-914$

Rossi P, Dolci S, Albanesi C, Grimaldi P, Ricca R and Geremia R (1993) Folliclestimulating hormone induction of Steel factor (SLF) mRNA in mouse Sertoli cells and stimulation of DNA synthesis in spermatogonia by soluble SLF Developmental Biology 155 68-74 
Russell ES (1979) Hereditary anemias of the mouse: a review for geneticists Advanced Genetics 20 357-459

Sawada K, Sakamaki K and Nishimune $Y$ (1991) Effect of the W mutation, for white belly spot, on testicular germ cell differentiation in mice Journal of Reproduction and Fertility 93 287-294

Seamon KB, Padgett W and Daly JW (1981) Forskolin: unique diterpene activator of adenylate cyclase in membranes and in intact cells Proceedings of the National Academy of Sciences USA 78 3363-3367

Skinner MK (1991) Cell-cell interactions in the testis Endocrine Reviews 12 45-77

Skinner MK and Griswold MD (1982) Secretion of testicular transferrin by cultured Sertoli cells is regulated by hormones and retinoids Biology of Reproduction 27 211-221

Stein J, Borzillo GV and Rettenmier CW (1990) Direct stimulation of cells expressing receptors for macrophage colony-stimulating factor (CSF-1) by a plasma membrane-bound precursor of human CSF-1 Blood 76 1308-1314
Tajima Y, Onoue H, Kitamura Y and Nishinume Y (1991a) Biologically active kit ligand growth factor is produced by mouse Sertoli cells and is defective in $\mathrm{Sl}^{d}$ mutant mice Development 113 1031-1035

Tajima Y, Sakamaki K, Watanabe D, Koshimizu U, Matsuzawa T and Nishimune $\mathbf{Y}(1991 \mathrm{~b})$ Steel-Dickie $\left(S \mathrm{~S}^{\mathrm{d}}\right)$ mutation affects both maintenance and differentiation of testicular germ cells in mice Journal of Reproduction and Fertility 91 441-449

Tung P, Skinner MK and Fritz IB (1984) Fibronectin synthesis is a marker for peritubular cell contaminations in Sertoli cell-enriched cultures Biology of Reproduction 30 199-211

Witte ON (1990) Steel locus defines new multipotent growth factor Cell 63 $5-6$

Yoshinaga K, Nishikawa S, Ogawa M, Hayashi S, Kunisada T, Fujimoto T and Nishikawa S-I (1991) Role of c-kit in mouse spermatogenesis: identification of spermatogonia as a specific site of $\mathrm{c}$-kit expression and function Development $113689-699$ 